\title{
Microhabitat selection and co-occurrence of Pachistopelma rufonigrum Pocock (Araneae, Theraphosidae) and Nothroctenus fuxico sp. nov. (Araneae, Ctenidae) in tank bromeliads from Serra de Itabaiana, Sergipe, Brazil
}

\author{
Sidclay Calaça Dias ${ }^{1} \&$ Antonio D. Brescovit ${ }^{2}$ \\ 1 Programa de Pós-Graduação em Ciências Biológicas, Zoologia, Departamento de Sistemática e Ecologia, Universidade \\ Federal da Paraíba. 58059-900 João Pessoa, Paraíba, Brasil. E-mail: pachistopelma@hotmail.com \\ 2 Instituto Butantan, Laboratório de Artrópodes. Avenida Vital Brazil 1500, 05503-900 São Paulo, São Paulo, Brasil. \\ E-mail: adbresc@terra.com.br
}

\begin{abstract}
Microhabitat selection and co-occurrence of Pachistopelma rufonigrum Pocock (Theraphosidae) and Nothroctenus fuxico sp. nov. (Ctenidae), in tank bromeliads were investigated. Thermal conditions, inside and outside the plants, were measured in order to verify if the temperature of the water that accumulates inside the plant affects the behavior of these species. Measurements of foliar parameters were taken in order to evaluate if and how plant structure affects spider abundance and microhabitat selection. Apparently, differences in plant structure do not affect either spider abundance or microhabitat selection. No microhabitat preference was observed and co-ocurrence of both species was a random event. In addition, notes on the distribution range of P. rufonigrum and the description of $N$. fuxico sp. nov. from State of Sergipe, Brazil are presented.
\end{abstract}

KEY WORDS. Microhabitat preference, inter specific co-existence, spiders, terrestrial's bromeliads, thermal conditions.

RESUMO. Foram estudadas a seleção de microhabitat e co-ocorrência de Pachistopelma rufonigrum Pocock (Theraphosidae) e Nothroctenus fuxico sp. nov. (Ctenidae) em bromélias-tanque. A condição da temperatura dentro e fora das plantas foi medida para verificar se a temperatura da água acumulada dentro da bromélia afeta algum aspecto comportamental das aranhas que ali vivem. Medidas dos parâmetros foliares foram realizadas para avaliar se a estrutura das plantas chega a afetar a abundância ou a seleção de microhabitat dessas aranhas. Aparentemente, as diferenças na estrutura das duas espécies de bromélias estudadas não afetam nem a abundância, nem a seleção de microhabitat de P. rufonigrum e $N$. fuxico sp. nov. A preferência e co-ocorrência de ambas as espécies de aranhas parece ser um evento ao acaso. Adicionalmente, apresenta-se notas sobre os limites de distribuição de P. rufonigrum e descreve-se $N$. fuxico sp. nov. do Estado de Sergipe, Brasil.

PALAVRAS CHAVE. Aranhas, bromélias terrestres, condições termais, co-ocorrência interespecífica, preferência por microhabitat.

Spiders use bromeliads for several means. Some species use the plants as reproductive sites (BARTH et al. 1988, Dias et al. 2000, Rossa-Feres et al. 2000, Dias \& Brescovit 2003), for foraging (Dias $\&$ BRESCOVIT 2003) or even as a shelter against desiccation (BARTH et al. 1998). Although there are several papers that deal with the relationship between spiders and host plants, none present information on the co-occurrence and niche overlapping of large spiders. According to PIANKa (1994) niche overlapping occurs when two organisms use the same resources in a same habitat and this overlapping can result in a competition for resources. Several well-documented examples have been presented on tactics to avoid competition in niche overlapping species (Robinson 1981, Scheidler 1990, Pianka 1994). Robinson (1981), while studying the effects of habitat structure over spi- der species composition, concluded that different species in a community show a preference towards different substrate structures as a means to prevent competition for resources.

In the Serra de Itabaiana, Sergipe, Brazil, two terrestrial tank bromeliad species of the genera Aechmea Ruiz \& Pav. and Hohenbergia Schult, host large spiders of the families Theraphosidae (Pachistopelma rufonigrum Pocock, 1901) and Ctenidae (Nothroctenus fuxico sp. nov.). All stages of the life cycle of both species have been recorded inside the plants, confirming that the bromeliads are used as a reproduction site and that the spiders are probably associated exclusively to these plants throughout their entire life cycle (Dias et al. 2000, Dias \& BRESCOVIT 2003). The aims of this study were to investigate the preference of these spiders towards any of the plant species, 
the co-occurrence of species in a same plant, the effects of thermal conditions on their foraging behavior and of habitat structure on species abundance. In addition to the natural history data, the description of the new species of N othroctenus Badcock, 1932 as well as notes on the northeastern distribution range of P. rufonigrum are presented.

\section{MATERIAL AND METHODS}

This study was carried out in the "Estação Ecológica Serra deltabaiana”, Areia Branca (1040'S; 37²5'W), State of Sergipe, Brazil, between July and September 2002. The area is characterized by the presence of white sandy soil and vegetation composed mainly of shrubs, bushes, bromeliads and cactus (VICENTE et al. 1997). The data were collected between the "Água Fria" and "Coqueiro" streams and between "Água Fria" and "Negros" streams.

The data on co-occurrence and preference were based on the number of specimens recorded in 80 plants of each species. Since both spider species are nocturnal, plants were marked during the day and observations were made during the night. Temperature measurements were taken, inside and outside 20 tank bromeliads, at three different time spans: between 0700 $0800 \mathrm{~h}, 1200-1300 \mathrm{~h}$ and $1730-1830 \mathrm{~h}$. In order to determine the total leaf surface of the bromeliad species, the number of live leaves of 20 plants of each species was counted and the length and width of one leaf from the median layers of the plant was measured. All measurements were taken in centimeters.

Chi-square tests were used to determine if there was a preference towards a specific microhabitat and if there was cooccurrence of species (SIEGEL 1997). The t-test, used for independent samples, was used to compare the temperature between the inside and outside of the plants as well as to determine if there were differences between the average of foliar surface and the number of live leaves of the two bromeliad species (VANZOLINI 1993, ZAR 1996).

Systematic description format, leg spination and terminology follow HöfER et al. (1994). All measurements are in millimeters. Abbreviations: (AME) anterior median eyes; (PME) posterior median eyes; (ALE) anterior lateral eyes; (PLE) posterior lateral eyes; $(p)$ prolateral; $(r)$ retrolateral; $(d)$ dorsal. The epigynum was dissected and submerged in clove oil to study internal structures. Micrographs were obtained with a JEOL scanning electron microscope (JSM 840A) from the “Laboratório de Microscopia El etrônica do Departamento de Física Geral do Instituto de Física da Universidade de São Paulo (USP)".

\section{RESULTS}

\section{Microhabitat preference}

Only two species of tank bromeliads are found in the Serra de Itabaiana region. The proportion of individuals of each species in the area is the same.

Thirty-two P. rufonigrum specimens were observed inhab- iting bromeliads amongst 160 examined plants, 80 of each species. As shown on tablel, there was no preference of this spider towards any of the bromeliad species $\left(\chi^{2}=0.0312, p>0.05\right)$.

In relation to $\mathrm{N}$. fuxico sp. nov., 32 specimens were observed amongst the 160 examined plants and no preference towards any of the species was observed, as shown on table I $\left(\chi^{2}=0.0192, p>0.05\right)$.

\section{Co-occurrence of spiders}

DIAS \& BRESCOVIT (2003) observed that P. rufonigrum and $\mathrm{N}$. fuxico sp. nov. are sometimes found inhabiting the same plant. According to the data obtained in this study, the cooccurrence of spiders occurs at random. For Aechmea sp. $\chi^{2}=$ $0.0334, p>0.05$ and for Hohenbergia sp. $\chi^{2}=0.0908, p>0.05$.

\section{Temperature}

Since both species of plants accumulate pluvial water inside of their central tank, the temperature inside the plant is the same as that of the accumulated water and as such, directly influenced by the environmental temperature. Nevertheless, the temperature inside of the plants was lower or higher than that of the outside, on morning and night, respectively. table II, with the Student t-tests results, shows when there was a significant difference between the temperature inside and outside of the plant.

\section{Foliar parameters}

Although the tank bromeliad species found in the "Serra de Itabaiana" are very similar, both presenting central tanks and a spiraled leaf arrangement that accumulates rainwater, comparisons of the foliar parameter showed significant differences. Hohenbergia bromeliads present more leaves than Aechmea ( $t=-4.75$, d.f. $=38, p<0.01$, Fig. 1 ). Nevertheless, Aechmea bromeliads present larger foliar surfaces than Hohenbergia ( $t=4.65$, d.f. $=38, p<0.01$, Fig. 2 ).

\section{Systematics}

The spider species dealt in this paper belong to two different orders. P. rufonigrum belongs to the order Mygalomorphae, amply distributed throughout the Brazilian Northeastern coastland and semi-arid regions. The genus Pachistopelma Pocock, 1901 includes only two species P. concolor Caporiacco, 1947, restricted to the Guyana, and the abovementioned species (PLATNICK 2003). Notes on the behavior of the P. rufonigrum were presented by DIAS \& BRESCOVIT (2003). In this paper data on the distribution range of $P$. rufonigrum is presented based on material from the collections of the Instituto Butantan, São Paulo (IBSP) and Museu Nacional do Rio de Janeiro, Rio de Janeiro (MNRJ).

The other species, belonging to the order Araneomorphae, is an undescribed species of the genus $N$ othroctenus Badcock, 1932. This genus includes, to date, eight Neotropical species, six of which are recorded from Brazil (PLATNICK 2003). This new species is probably the only one with morphological adaptations for living in bromeliads. 

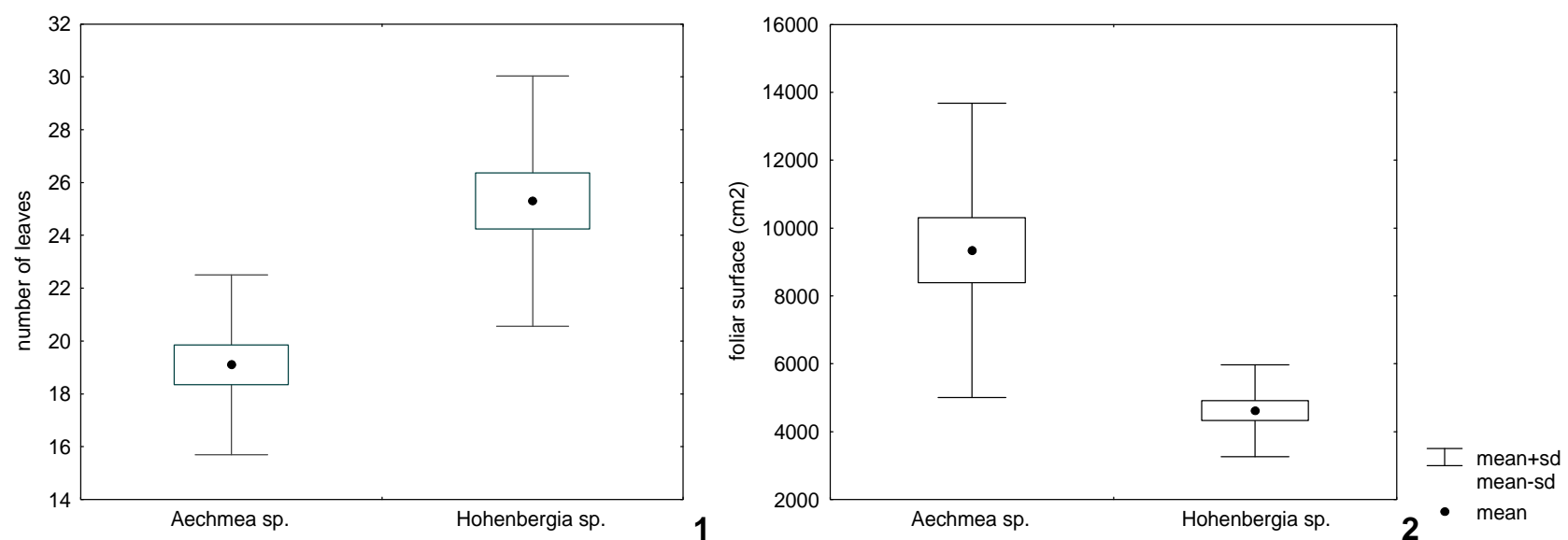

Figures 1-2. (1) Comparison between the average number of leaves in the two bromeliad species; (2) Comparison between the average foliar surface in the two bromeliads species.

Table I. Microhabitat preference for P. rufonigrum and N. fuxico sp. nov. (F) Observed frequency of spiders, (E) expected frequency.

\begin{tabular}{|c|c|c|c|c|c|c|}
\hline \multirow{2}{*}{ Habitat } & \multicolumn{3}{|c|}{ P. rufonigrum } & \multicolumn{3}{|c|}{ N. fuxico sp. nov. } \\
\hline & $\mathrm{F}$ & $\bar{E}$ & $\chi^{2}$ (with Yates correction) & $\mathrm{F}$ & $E$ & $\chi^{2}$ (with Yates correction) \\
\hline Aechmea (50\%) & 16 & 16 & 0.0156 & 25 & 26 & 0.0096 \\
\hline Hohenbergia (50\%) & 16 & 16 & 0.0156 & 27 & 26 & 0.0096 \\
\hline Total & 32 & 32 & $x^{2}=0.0312$ & 52 & 52 & $\chi^{2}=0.0192$ \\
\hline
\end{tabular}

Table II. Student t-tests comparing the average difference of temperature inside and outside of the tank bromeliads, at three different times during the day. (x) Average, (sd) standard deviation.

\begin{tabular}{llllrr}
\hline \multicolumn{1}{c}{ Specie } & \multicolumn{1}{c}{ Period } & $\mathrm{x} \pm$ sd T ${ }^{\circ} \mathrm{C}$ plant & $\mathrm{x} \pm$ sd T ${ }^{\circ} \mathrm{C}$ air & $\mathrm{t}$ values (d.f. $=38)$ & $\mathrm{p}$ \\
\hline Aechmea & Morning & $21.85 \pm 0.671$ & $22.92 \pm 0.907$ & -4.261 & $<0.01$ \\
Aechmea & Midday & $24.80 \pm 1.196$ & $24.52 \pm 1.141$ & 0.740 & $>0.05$ \\
Aechmea & Night & $23.32 \pm 1.029$ & $21.77 \pm 0.617$ & 5.774 & $<0.01$ \\
Hohenbergia & Morning & $22.22 \pm 0.638$ & $24.42 \pm 0.892$ & -8.968 & $<0.01$ \\
Hohenbergia & Midday & $26.42 \pm 1.238$ & $25.67 \pm 1.290$ & 1.875 & $>0.05$ \\
Hohenbergia & Night & $25.80 \pm 0.732$ & $22.77 \pm 0.785$ & 12.593 & $<0.01$ \\
\hline
\end{tabular}

\section{Padistopelma rufonigum Pocock, 1901}

Fig. 3

Pachistopel ma rufonigrum Pocock, 1901: 548 (2 males and 6 femal es paratypes from Igarassú, Pernambuco, Brazil, deposited in the The Natural History Museum, London, not examined); Mello-Leitão, 1923: 336; Brescovit et al., 1999: 108; Rocha-Neto, 2001: 28; Platnick, 2003.

Distribution. Northeastern Brazil, living exclusively in bromeliads.

Records. BraziL, Rio Grande do N orte: Extremóz, Pitangui (in Rocha-Neto 2001); Pernambuco: Moreno, Bonança (MNRJ 13615); Paraíba: Mamanguape (IBSP 9756); Sergipe: Nossa Senhora da Glória (IBSP 7892; 7893); Brejo Grande (IBSP 8085);
Barra dos Coqueiros (IBSP 8086; 8087; 8088); Areia Branca, Estação Ecológica Serra de Itabaiana (IBSP 8525; 8599; 8716; 9147; 9789; 8698; 9832; 10010; 10011; 10035); Santa Luzia do Itanhy, Mata do Crasto (in Brescovit et al. 1999).

\section{Nothroctenus fuxico sp. nov.}

Figs 4-18

Types. Holotype male and allotype female from Estação Ecológica Serra de Itabaiana, Areia Branca, Sergipe, 09.IX.2000, S.C. Dias leg., deposited in Instituto Butantan (IBSP 37834). Paratypes: 1 male, 1 female with the same data as holotype, N. Zyngier leg. (IBSP 37835); 1 female from Barra dos Coqueiros, Sergipe, 20.II.1995, E.C.G. Couto eL.T. dos Santosleg. (IBSP 24002). 

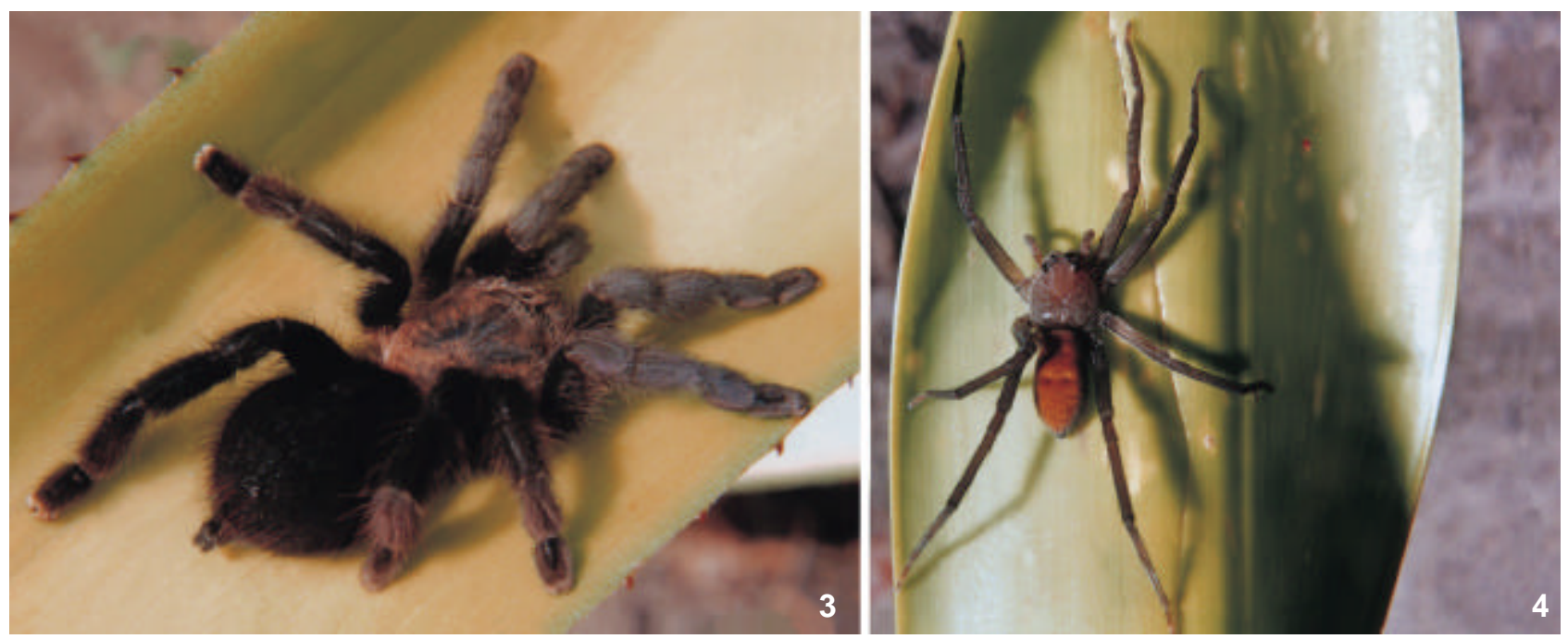

Figures 3-4. (3) Pachistopelma rufonigrum on leaves of Hohenbergia sp. bromeliad, adult female; (4) Nothroctenus fuxico sp. nov. on leaves of Aechmea sp. bromeliad, adult female.

Etymology. Brazilian northeastern slang that means friendship, due to the fact that this species is commonly observed living together with P. rufonigrum in the tank bromeliads.

Diagnosis. Nothroctenus fuxico sp. nov. is easily distinguished from the other species of this genus by the flattened body (Figs 4 and 6) and modified eye area, where the PME are located almost between the AME and ALE (Figs 5-6).

Description. Male (Holotype). Carapace brown, with cephalic area and posterior third of carapace orange; black rings around the eyes; chelicerae orange; labium, endites and sternum yellowish. Legs brown with distal area of the articles gray, coxae ventrally yellow and femora gray. Abdomen dorsally yellowish, laterally gray and ventrally yellow to orange.

Total length 11.80. Carapace 6.20 long, 5.00 wide. Clypeus 0.04. Eye diameters and inter distances: AME 0.26, ALE 0.20, PME 0.56, located al most between the AME and ALE (Figs 5-6), PLE 0.62; AM E-AME 0.10, AM E-ALE 0.72, PME-PME 0.28, PME-PLE 0.56, AME-PLE 0.50, AME-PME 0.10. MOQ length 0.68 , anterior width 0.64 , posterior width 1.56 . Chelicerae with 3 promarginal teeth, the median the largest, and 3 retromarginal denticles.

Leg measurements. I - femur 7.70/patella 3.00/tibia 8.20/ metatarsus 8.80/tarsus 2.00/total 29.70/II - 7.40/2.80/7.10/7.70/ 1.80/26.80/III - 6.20/2.20/5.20/6.70/1.50/21.80/IV- 8.20/2.30/ 7.60/9.30/2.30/29.70. Leg spination: femur I p1-1-2-1-1, d1-11, r1-1-1; II - IV p1-1-1-1, d1-1-1, r1-1-1-1; trochanter I - II r01-0, III - IV r0-1-0; tibia I v2-2-2-2-2, p1-1-1-1-1, r0-1-1; II v2-22-2-2-2-2, p1-0-0, r1-1-1-1-1; III - IV v2-2-2, p 1-1-0, r1-1-0; metatarsus I v2-2-2-2, p1-1-1-1, r1-1-1-1; II v2-2-2-2, p1-1-0, r1-1-1-1; III v2-2-2-2, p1-1-1, r1-1-1; IV v2-2-2-2, p1-1-1, r1-1-
1. Cribellum inconspicuous, not divided, calamistrum absent. Pal pal spination: femur p1, d1-1, r1. Palp: tibia with retrolaterobasal enlargement and tibial retrolateral apophysis short, sinuous and curved at tip (Fig. 7); cymbium with median retrolateral projection (Fig. 8) and distal area with 13-15 very thick spines (Fig. 15); tegulum with sinuous and retrolateral reservoir, median apophysis short and curved at apex, conductor with long and very thick basis, distally with great number of short projections and presenting a hyaline area involving the tip of embolus, embolus very long, with large basis and narrow and sinuous distal area (Figs 7; 13-14).

Female (Allotype). Coloration as in male, except chelicera, endites, labium and sternum red-brown (Fig. 4).

Total length 12.80. Carapace 5.90 long, 4.90 wide. Clypeus 0.15 high. Eye diameters and interdistances: AME 0.25, ALE 0.25, PME 0.60, as in the male, PLE 0.70; AME-AME 0.20, AME-ALE 0.15, PME-PME 0.75, PME-PLE 0.75, ALE-PLE 0.40, AME-PME 0.06. MOQ length 1.30, anterior width 1.65, posterior width 1.95. Chelicerae as in male.

Leg measurements. I - femur 5.70/patella 2.80/tibia 5.80/ metatarsus 5.40/tarsus 1.20/total 20.90/II - 5.80/2.60/5.20/5.20/ 1.10/19.90/III - 5.10/2.00/4.00/4.60/1.00/16.70/IV - 6.40/2.30/ $5.50 / 6.40 / 1.40 / 22.00$. Leg spination: femur as in male; tibia I v2-2-2-2-2-2, p1-1-0, r1-1-1; II v2-2-2-2-2-2-2, p1-1-1-1, r1-1-11-1; III - IV v2-2-2, p1-1-0, r1-1-0; metatarsus I v2-2-2-2, p1-00, p1-0-0, II v2-2-2-1p, p1-0-0, r1-0-0, III v2-2-2, p1-2-2, r1-2-2, IV v2-2-2, p1-1-1-2, r1-1-1-2. Leg IV with long claws with only three small ventral teeth and developed claw tufts (Fig. 16). Trichobothria with long trichoma, bothrium with transverse and striated ring (Fig. 17). Tarsal organ capsulated with oval opening (Fig. 18). Cribellum not divided, calamistrum brush- 

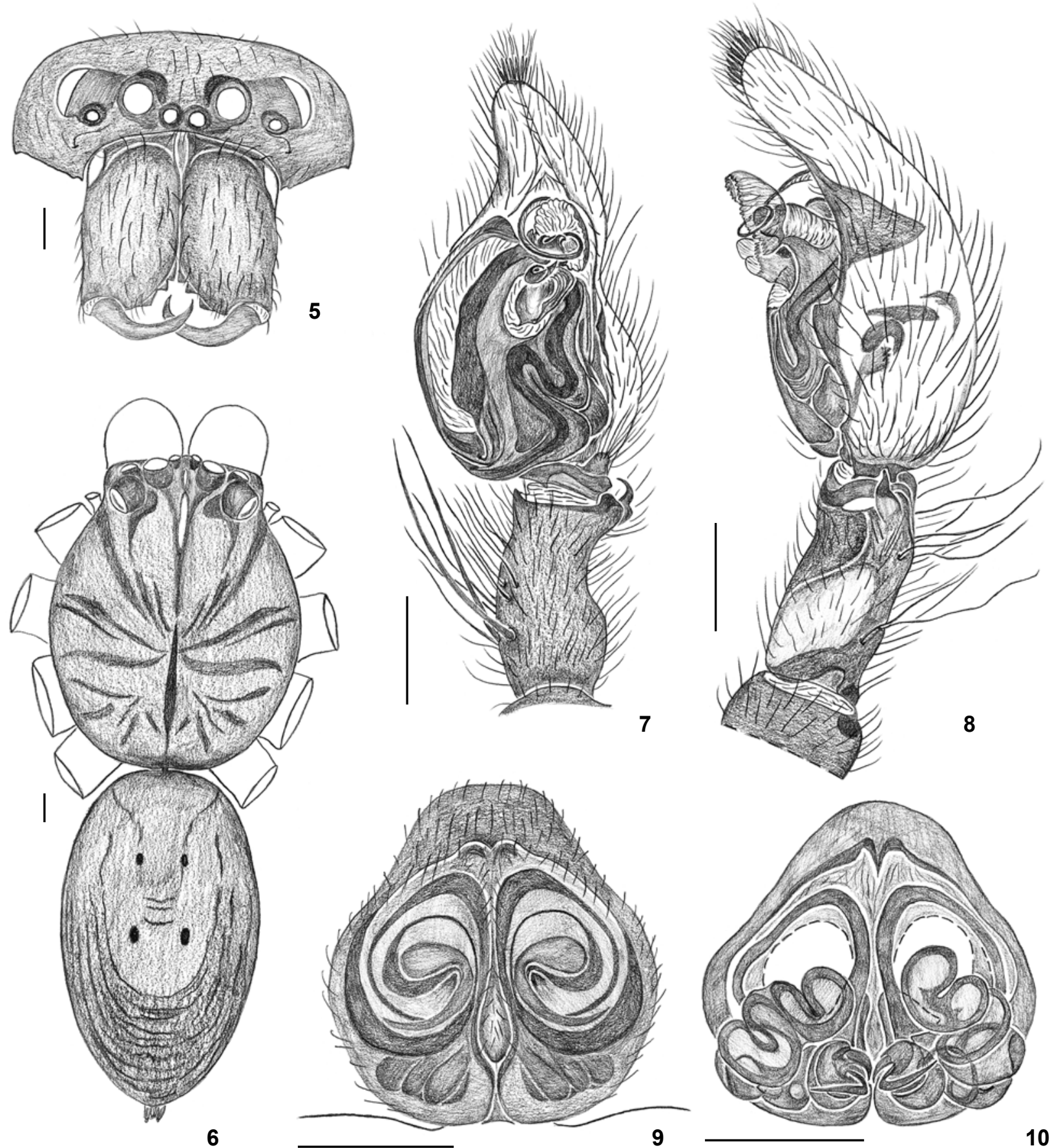

Figures 5-10. Nothroctenus fuxico sp. nov.: (5) carapace, female, frontal, (6) Habitus, female, dorsal, (7-8) male palp: (7) ventral, (8) retrolateral; (9-10) female epigynum: (9) ventral, (10) dorsal. Scale bars: 0,5 mm.

like, from base to top of tibia and presenting hairs with modified lateral surfaces (Figs 11-12). Epigynum with circular atrium divided by a median septum with a median, short and finger- like scapus (Fig. 9). Internally with long and narrow copulatory ducts, large and coiled spermathecae and short, narrowed and basal fertilization ducts (Fig. 10). 

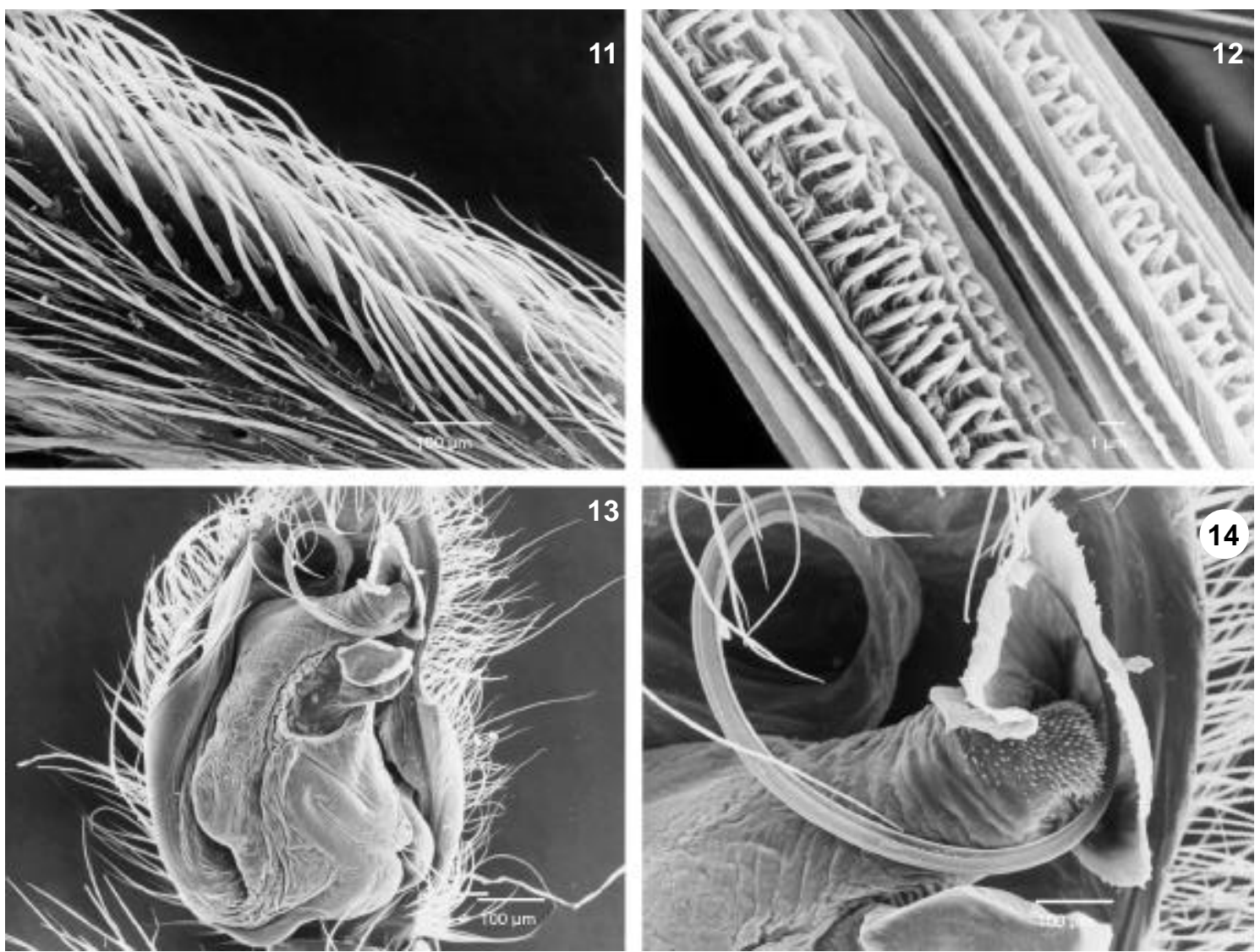

Figures 11-14. Nothroctenus fuxico sp. nov. (11-12) female calamistrum, leg IV: (11) lateral, (12) detail of hairs, lateral; (13-14) male palp: (13) ventral, (14) detail of apex, conductor and embolus, ventral.

Variation. Three males: total length 10.80-12.00; carapace 5.30-6.20; femur I 6.80-7.70; six females: total length 12.60-15.80; carapace 5.60-6.80; femur I 5.60-6.80.

Distribution. Only known from thestate of Sergipe, Brazil.

Other material examined: BrazlL. Sergipe: Areia Branca, Estação Ecológica Serra de Itabaiana, 5 juveniles, VII-IX.2000, N. Zyngier \& S.C. Dias leg. (IBSP 37386; 37837; 37838); Barra dos Coqueiros, 1 male and 3 females, XI.1994-X.1998, E.C.G. Couto \& L.T. Santos leg. (IBSP 24001; 24005; 37839; 37840).

\section{DISCUSSION}

There was no preference of the spiders' towards any bromeliad species, even though there were significant differences in the number of leaves and foliar surface of the plants. Nevertheless, differences in foliar parameters could be a reason for the spiders' preference towards one bromeliad species. HATLEY \& MACMAHON (1980) observed that the number of leaves of a shrub indicated the amount of available substrate for spiders and as such, shrubs with more leaves have more resident spiders than those with less foliage. PIANKA (1966) obtained the same results while studying lizards. He showed that more the larger the volume of the dwelling plant, the higher the fauna diversity associated to it. Although Hohenbergia has more leaves than Aechmea, thelatter has a larger foliar surface. Assuch, the quantity of availablemicrohabitats that could beoccupied in both plants is virtually the same, since the higher number of leaves is compensated by the larger foliar surface and vice-versa. This is probably the reason why no preference was observed in the studied spiders.

DIAS \& BRESCOVIT (2003) state that, for P. rufonigrum, only one spider occurs in each plant. This is probably also the case for N. fuxico sp. nov., since both species are quite large and the bromeliad has enough resources for only one spider. The data obtained in this study shows that $\mathrm{N}$. fuxico $\mathrm{sp}$. nov. and $\mathrm{P}$. rufonigrum do not co-occur in the same plant. In other words, the spiders prefer inhabitting separate plants so that there is no niche overlapping. DIAS \& BRESCOVIT (2003) found P. rufonigrum and $\mathrm{N}$. fuxico sp. nov. in the same bromeliad in few cases. Nevertheless, no agonistic encounters between the species were recorded. One reason can be appointed to the competition excluded hypothesis between these two species of spi- 

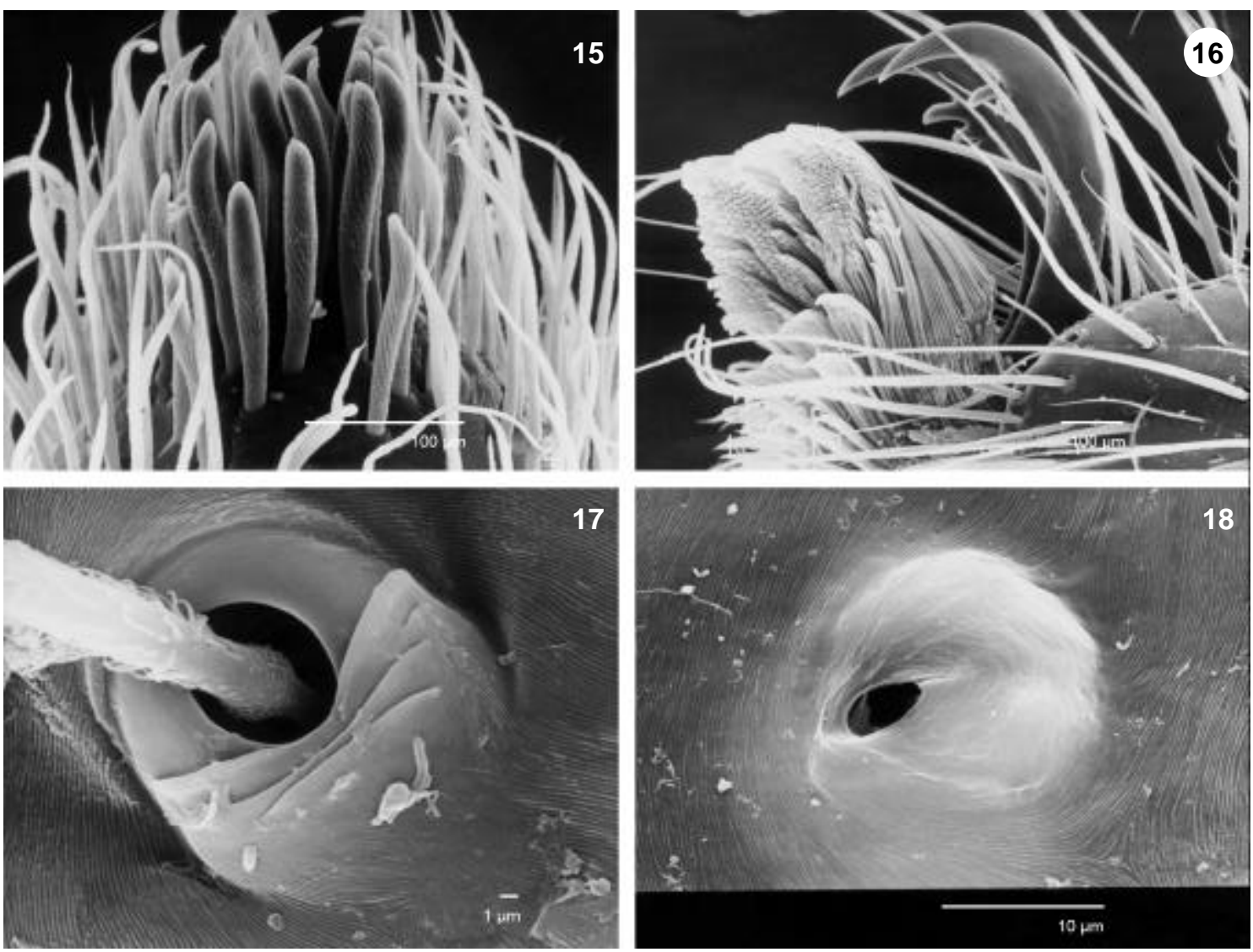

Figures 15-18. N othroctenus fuxico sp. nov.: (15) male palp, cymbium, apex ventral; (16) female, leg IV, detail of claws and subungueal hairs; (17) Trichobothria, leg I, dorsal; (18) tarsal organ, leg I, dorsal.

ders that is the strategies foraging difference. WhileP. rufonigrum have a mode sit and wait of strategy foraging (DIAS \& BRESCOVIT 2003), N. fuxico sp. nov. it can be, like the major of Ctenidae, actives hunter and, therefore, must be feed it of different prey. Due to the fact that both species include large animals, it is believed that a single bromeliad does not haveenough resources to enable two spiders to live in it. Several papers deal with the relation between population density and body size in many groups of animals (DamUth 1981, Peters \& Wassenberg 1983, GUNARSSON 1992, M ORSE et al. 1988, LAWTON 1989). DAMUTH (1981) states that there is an inverse relation between body size and local abundance and that two distinct patterns can be observed for population densities: a large number of small individuals or a small number of large individuals. The same conclusions were presented by Gunnarsson (1992) for spiders, Peters \& W ASSENBERG (1983), while dealing with several studies of different authors on a variety of animal groups, and by MORSE et al. (1988), for beetles.

Tank bromeliads are important microhabitats for their associated biota. In addition to the protection against predators offered by the bromeliad leaves, the water accumulated in the central tank acts as a thermoregulation mechanism, providing a microclimate different to that of the external environment. SCHEIDLER (1990) states that plant structure affects abiotic factors, such as temperature. BARTH et al. (1998) observed significant differences between temperature and humidity inside and outside the bromeliads, reporting higher humidity values inside the bromeliads. VRCIBRADIC \& RoCHA (2002), while working with cactus in the Brazilian "restinga", verified that the temperature of the accumulated water inside the plants varies in relation to air temperature according to a physical component, known as specific heat. According to these authors, if the air temperature decreases, the water insidethe plant remains warmer a little longer. This fact was also verified in this study, with significant differences between the temperature insideand outside the plant. This does not mean that the temperature of the water inside the plant was al ways lower than that of the outside. We believe that temperature is one of the main factors affecting the spiders' behavioral cycle. For the spiders it is best to remain inside the bromeliad during the morning, when the temperature 
is lower than that of the outside. At nightfall, the spiders tend to leave the plants. This can be explained by the fact that the temperature is lower outside the plant and that both spider species' diet is composed of nocturnal animals. Both species prefer to remain inside the bromeliad during the day not only because the leaves provide protection against direct sun radiation but also because the high humidity, provided by the water accumulated inside the central tank, prevents desiccation, even if the temperatures inside and outside the plant are the same.

\section{ACKNOWLEDGMENTS}

Wewish to thank AlexandreVasconcellos (UFPB), Glauco Machado (UNICAMP), Gustavo Q. Romero (UNICAMP) and Malva I. M. Hernández (UFPB) for critical review of the initial drafts of this manuscript; Gustavo Q. Romero for help with the elaboration of the field methodology and for obtaining and sending copies of several references; to Everton Amancio (CNPq) for obtaining and sending copies of references; Cristina A. Rheims (IBSP/USP) for review of the English version of the text; to Valdineide Barbosa and Marleno Costa (IBAMA, SE) for logistic support; to Capes (SCD), CNPq (ADB) and FAPESPBIOTA (99/05446-8; ADB) for financial support.

\section{REFERENCES}

Barth, F.G.; E.A. Seyfarth; H. Bleckman \& W. Schüch. 1988. Spiders of the genus Cupiennius Simon 1891 (Araneae, Ctenidae). I. Range distribution, dwelling plants, and climatic characteristics of the habitats. Oecologia, Berlin, 77: 187-193.

Brescovit, A.D.; A.C.M. Fernandes \& E.C.G. Couto. 1999. Aranhas da "M ata do Crasto" (Santa Luzia do Itanhy - SE). In: Anais do VII Congresso Nordestino de Ecologia, Ilhéus, p. 108-110.

DAмUтH, J. 1981. Population density and body size in mammals. Nature, London, 290: 699-700.

DiAs, S.C. \& A.D. Brescovit. 2003. Notes on the behavior of Pachistopelma rufonigrum Pocock (Araneae, Theraphosidae, Aviculariinae). Revista Brasileira de Zoologia, Curitiba, 20 (1): 13-17.

Dias, S.C.; A.D. Brescovit; L.T. Santos \& E.C.G. Couto. 2000. Aranhas em bromélias de duas restingas do Estado de Sergipe, Brasil. Biologia Geral e Experimental, São Cristóvão, 1 (1): 22-24.

GunNARSSON, B. 1992. Fractal dimension of plants and body size distribution in spiders. Functional Ecology, London, 6: 636641.

HATLEY, C.L. \& J.A. MACM AHON. 1980. Spider community organization: seasonal variation and the role of vegetation architecture. Enviromental Entomology, Pennsylvania, 9 (5): 632-639.

Höfer, H.; A.D. Brescovit \& T. GASNIER. 1994. Thelarge wandering spiders of the genus Ctenus (Ctenidae, Araneae) of Reserva Ducke, a rainforest reserve in Central Amazonia. Andrias, Karlsruhe, 13: 81-98.

LAWTON, J.H. 1989. What is the relationship between population density and body size in animals? Oikos, Copenhagen, 55 (3): 429-434.

MelLo-Leitão, C. F. DE. 1923. Theraphosideas do Brasil. Revista do Museu Paulista, São Paulo, 13: 1-438.

MorSE, D.R.; N.E. Stork \& J.H. LaWton. 1988. Species number, species abundance and body length relationships of arboreal beetles in Bornean lowland rain forest trees. Ecological Entomology, London, 13: 25-37.

Peters, R.H. \& K. Wassenberg. 1983. The effect of body size on animal abundance. Oecologia, Berlin, 60: 89-96.

PiANKA, E.R. 1966. Convexity, desert lizards, and spatial heterogeneity. Ecology, Washington, 47 (6): 1055-1059.

. 1994. Evolutionary Ecology. New York, Harper Collins, $5^{\text {th }}$ ed., $486 \mathrm{p}$.

PlatNICK, N.I. 2003. Theworld spider catalog, version 3.5. American Museum of Natural History, online at http://research.amnh. org/entomology/spiders/catalog81-87/index.html

Pocock, R.I. 1901. Somenew and old genera of South American Avicularidae. Annals Magazine of Natural History, London, 8 (7): 540-555.

Robinson, J.V. 1981. The effect of architectural variation in habitat on a spider community: an experimental field study. Ecology, Washington, 62 (1): 73-80.

Rocha Neto, M. 2001. Guia ilustrado: fauna da escola das Dunas de Pitangui - ecossi stemas terrestres. Natal, Miguel Rocha Neto (Ed.), 114p.

Rossa-Feres, D de C.; G.Q. Romero; E. Gonçalves-de-Freitas \& R.J.F. FERES. 2000. Reproductive behavior and seasonal occurance of Psecas viridepurpureos (Salticidae, Araneae). Revista Brasileira de Biologia, Rio de Janeiro, 60 (2): 221-228.

SCHEIDLER, M. 1990. Influence of habitat structure and vegetation architecture on spiders. Zoologischer Anzeiger, Leipzig, 225 (5/6): 333-340.

SIEGEL, S. 1977. Estatística não-paramétrica (para as ciências do comportamento). São Paulo, McGraw-Hill, 2ª ed., 349p.

VANZOLINI, P.E. 1993. M étodos estatísticos el ementares em sistemática zoológica. São Paulo, Hucitec, 130p.

Vicente, A., G.M.M. Araújo, G.P. Lírıo Jr. \& S.C. Santos. 1997. Descrição preliminar e parcial dos habitats da Serra de Itabaiana. Publicações Avulsas do Calb, São Cristóvão, 1: 7-21.

VRCIBRADIC, D. \& C.F.D. RochA. 2002. Use of cacti as heat sources by thermoregulating Mabuya agilis (Raddi) and Mabuya macrorhyncha Hoge (Lacertilia, Scincidae) in two habitats in southeastern Brazil. Revista Brasileira de Zoologia, Curitiba, 19 (1): 77-83.

ZAR, J.H. 1996. Biostatistical Analysis. New Jersey, Prentice Hall, $3^{\text {th }}$ ed., 662p.

Received in 25.XI.2003; accepted in 06.X.2004.

Revista Brasileira de Zoologia 21(4): 789-796, dezembro 2004 